\title{
EDITORIAL
}

\section{MOST AND LEAST OF RESEARCH VALUE/S}

\section{Christian Ulrik Andersen \& Geoff Cox}

APRJA Volume 7, Issue 1, 2018

ISSN 2245-7755

CC license: 'Attribution-NonCommercial-ShareAlike'. 
There is value and there are values. There is the measure of wealth, metrified and calculated in numerous ways, and there are ideas, ethics, preferences of taste, and customs of ideology. That the two can be associated together is nothing new. It is easy to value values and quantify how well we like, prefer or perform values (on a scale from one to ten; and ironicized here in the reworking of this introduction by Pip Thornton). Likewise, such processes of valorization in themselves imply particular values, ideologies and ethical or aesthetical preferences (the beauty and rightfulness of valorization, wealth and surplus). But what really happens when the two are conflated? How do we understand how the values associated with something give it value; or, how giving something a value affords certain values? And, in what ways are the conflations of value and values tied to the circulation of value and values in contemporary technical infrastructures?

\section{Research values}

The articles published in A Peer-Reviewed Journal About Research Values interrogate value and values in ways that respond to techno-cultural shifts and embrace the range of economies that pervade digital culture. These include facing value and modes of subjectivation involved in both the sharing economy as well as in the use of biometrics (Luke Munn, Mitra Azar, Lea Laura Michelsen); knowing values and the different ways of storing and regulating knowledge (Francis Hunger, César Escudero Andaluz \& Martín Nadal, Maria Eriksson, Dionysia Mylonaki \& Panagiotis Tigas); activating values and the ways artists and activists may potentially address the conflation of values and value in terms of cultural politics (Marc Garrett, Ashley Lee Wong, Konstanze
Scheidt); and finally changing values to explore how processes of valuing and valorization seem to bend and evade fundamental relations to the world (Calum Bowden, Tega Brain).

This publication, then, also responds to the changing processes of valorization that qualify and quantify research, and follows an earlier research workshop at the Brandenburg Center for Media Studies (ZeM) in Potsdam, in which researchers exchanged ideas (and values) on face value, the theme of the 2018 edition of transmediale festival for digital art and culture in Berlin. And more precisely, the publication implicitly addresses how we may begin to think about the value and values associated with research processes and outputs?

\section{Value and valorization}

If we are to identify two classical thinkers on processes of valorization it must be Karl Marx and Immanuel Kant. In classical Marxism, the difference between a worker's wages (exchange value) and the value of goods and services s/he produces (use value) is referred to as surplus value (or added value). Since use value is higher than the exchange value, workers produce a positive surplus value through their labour, and this is what is exploited by the capitalist. It's so simple and enduring. Yes and No. Indeed some processes of valorization also evade capitalist values. In philosophical terms there are different processes of valorization, or 'judgments' as put by Kant. Judgements can be used to navigate or categorize what is definitely right or wrong according to function or ethics. But there are also more reflective judgements that work the other way around, by elevating the particular subjective experience to a universal truth that is not absolute 
or determinate, but open-ended and an expression of how things ought to be; shared by a community, a sensus communis.

So what are the relations between processes of (creative or academic) labour and surplus value, and processes of preferences, taste and even affect? There seems to be a shift, and to many also a crisis at play.

\section{Crisis of value}

The so-called 'crisis of value' can be understood as the struggle for control over the forces that - paradoxically - wish to extract surplus value from processes of valorization no longer so reliant on waged work-time or the monetized economy, but more tied to reflective judgements.

To some commentators (such as Benjamin Noys) the artist has become the paradigmatic worker demonstrating the required attributes of precarity and flexibility in today's capitalist production - and thus revealing this paradox of valorization. Artistic production is, and has always been, paradigmatic here with its complex and uneasy relation to the capitalist market and of the collapse between physical and symbolic forms of value. Despite the claims to reject its commodification by capital, this seems increasingly utopian under conditions where value outside of monetization has become commonplace; where valorization is a process of never-ending creations of judgments and formations of communities. In a situation where all production is post-conceptual, artist-workers demonstrate the paradigmatic attributes of flexibility and precarity. As Noys writes:
"This paradox is simply stated: on the one hand, the artist is the most capitalist subject, the one who subjects themselves to value extraction willingly and creatively, who prefigures the dominant trend lines of contemporary capitalism [...] on the other hand, the artist is the least capitalist subject, the one who resists value extraction through an alternative and excessive self-valorisation that can never be contained by capitalism."

\section{Most and least}

The most capitalist subject is the least capitalist subject at the same time, and what Marx once argued for the worker in general is exemplified by artistic production. Here lies the 'paradox of valorisation' - the most and least - and this is important for festivals for art and digital culture, like transmediale. We say this, as surely, the combination of art and digital culture is most and least contemporary capitalist production that typifies the ideological prescriptions of creative work, the use of scores, scripts, and programs, and the ways that core values have been incorporated into best and worst practices (e.g. sharing and modification). The case of open source software development and network services that have merged into centralized and monopolistic server-based platforms and services emphasizes the point (Andersen and Pold).

The paradox is clearly also important for research - as surely the researcher is a good further example of the most and least capitalist subject. Our point is to understand how research objects produce value, how they operate as exchange, and how they produce different kinds of socialities in their exchanges? What other socialities might we imagine once we recognize how value 
is subsumed into more complex humannonhuman assemblages? What kinds of value-machine imaginaries are possible that engender the most and least radical of value systems? This is responded to in this volume by researchers active in the (precarious) process of claiming value for their work.

Not least, nor most, this also points to the value of paradox itself.

Christian Ulrik Andersen \& Geoff Cox Aarhus/Plymouth, June 2018.

\section{Works cited}

Andersen, Christian Ulrik and Søren Bro

Pold. The Metainterface - The Art of

Platforms Cities and Clouds. Cambridge, London: The MIT Press, 2018. Print.

Cox, Geoff. "Paradoxical Values of Running Code." eds. Piotr Krajewski and Violetta Kutlubasis-Krajewska, Pioneering Values. Wroclaw: WRO Art Center, 2014, pp.41-46. Print.

Noys, Benjamin. The Art of Capital: Artistic Identity and the Paradox of Valorisation, 2011. Web <http://www.academia.

edu/689156/> 